\title{
МЕТОДИ БОРОТЬБИ 3 ШУМОВИМ ЗАБРУДНЕННЯМ У ЗОНАХ ВПЛИВУ ВЕЛИКИХ МІСТ
}

\section{METHODS OF COMBATING WITH NOISE POLLUTION IN ZONES INFLUENCE OF LARGE CITIES}

\section{Смаль М.В., к.т.н., доц., Дзюбинська О.В., ассистент, Сокур Т.Д., студент (Луцький національний технічний університет)}

Smal M.V., Ph.D. in Engineering, Associate Professor, Dzyubynska O.V., Assistant Professor, Sokur T.D., student (Lutsk National Technical University)

Анотація. Транспортне шумове забруднення продовжує збільшуватися разом із зростанням міст, щільністю міського населення та інтенсивністю транспортних перевезень. Повністю знизити рівень шуму неможливо, але є різні методи для його мінімізації, одним із яких є використанняя шумозахисних екранів.

Summary. The main sources of external noise in cities are: streams of all types of land road and rail transport; aviation transport at airports and zones of air routes of aerodromes; industrial enterprises and individual equipment; playgrounds of loading and unloading works objects of transport, trade, municipal and other enterprises and establishments; outdoor sports facilities and playgrounds; machines, mechanisms and technological equipment that perform construction, repair, cleaning and improvement of urban areas. Traffic flows on main streets and roads and trains are considered as linear sources of external noise in cities and all others as local. Due to the increase the level of motorization in Ukraine there is a problem of noise insulation and dust protection of buildings and structures located on roads of different purposes. Excessive noise can lead not only to physical discomforts but also to serious health problems, most commonly nervous system problems, cardiovascular disease, vision problems and increased fatigue. Transport noise contamination continues to increase with the growth of cities, urban population density, and the intensity of transport. Unfortunately, already today the noise level on the main highways of the cities is about $90 \mathrm{~dB}$, which is already higher than the norm, and this level is increased annually by $0.5 \mathrm{~dB}$.

It is impossible to completely reduce the noise level, but there are different methods to absorb it or to minimize it. They use different methods of sound insulation, one of which is the installation of noise shields. Depending of the principle of action, there are three main types of acoustic screens: absorbent, reflective, combined. According to the purpose, they are made of different materials, depending on which the screens can be transparent and opaque. Protective fences are constructed from materials with a high reflectance of sound wave energy. For this use: polycarbonate, glass, and rarely concrete. Often, these materials combine. In the article is described the classification of acoustic screens according to the principle of action and presented a comparative characteristic of the noise absorption of materials used in the manufacture of acoustic screens. 
Ключові слова: иум, звукопоглинаючі панелі, акустичні екрани.

Keywords: noise, soundabsorbing panels, acoustic screens.

Постановка проблеми. У зв'язку із підвищенням рівня автомобілізації в Україні постає проблема шумоізоляції та пилозахисту будівель і споруд, які знаходяться біля доріг різного призначення. Надмірний шум може призвести не лише до фізичних незручностей, а й до серйозних проблем зі здоров'ям, найчастіше це проблеми з нервовою системою, серцево-судинні захворювання, проблеми із зором та підвищення стомлюваності [1]. Науково доведено, що шум шкідливий не лише для людей, рослини під дією шуму ростуть повільніше, але рослини можуть звикнути до дії шуму, а люди не можуть до нього адаптуватись, тому потрібно вживати всі заходи для боротьби з ним.

На жаль, уже на сьогоднішній день рівень шуму на головних магістралях міст становить близько 90 Дб, що уже перевищує норму, і цей рівень щорічно збільшується на 0,5 Дб.

Формулювання цілей статті, постановка завдання. Головна мета дослідження полягає в розкритті проблем шумового забруднення міст та дослідженні методів щодо їх вирішення. Поставлені завдання: проаналізувати джерела шумового забруднення в містах, охарактеризувати організаційно-технічні методи боротьби 3 шумовим забрудненням; дослідити можливість використання акустичних екранів уздовж лінійних джерел шуму, як засобу боротьби з шумовим забруднення у містах.

\section{Виклад основного матеріалу дослідження.}

До основних джерел зовнішнього шуму у містах належать [2,3]:

- потоки усіх видів наземного автомобільного та рейкового транспорту;

- авіаційний транспорт в аеропортах та зонах повітряних трас аеродромів;

- промислові підприємства та окреме устаткування;

- майданчики вантажно-розвантажувальних робіт об'єктів транспорту, торговельних, комунально-побутових та інших підприємств i установ;

- відкриті спортивні споруди та ігрові майданчики;

- машини, механізми та технологічне устаткування, що виконують роботи 3 будівництва, ремонту, прибирання та благоустрою міських територій.

Транспортні потоки на магістральних вулицях та дорогах і залізничні потяги у русі розглядаються як лінійні джерела зовнішнього шуму у містах, а всі інші - як локальні.

Основною шумовою характеристикою джерел зовнішнього шуму у містах $\epsilon$ еквівалентний рівень звуку. У деяких випадках шум може оцінюватися максимальним рівнем звуку. 
Природний шум становить 20-30 Дб, цей рівень звуку нешкідливий для людини і не приносить незручностей. За санітарними нормами людина може переносити без особливої шкоди протягом тривалого часу шум до 40 дБА. Тому проблема зниження шуму має велике значення при покращенні умов навколишнього середовища. Гранично допустимі рівні звуку на територіях міської забудови [2] наведені в табл. 1.

Таблиця 1

\begin{tabular}{|c|c|c|c|}
\hline \multirow[b]{2}{*}{ Територія забудови } & \multirow{2}{*}{$\begin{array}{l}\text { Час } \\
\text { доби, } \\
\text { год }\end{array}$} & \multicolumn{2}{|c|}{$\begin{array}{c}\text { Гранично допустимі } \\
\text { рівні звуку,дБА }\end{array}$} \\
\hline & & $\begin{array}{c}\text { Еквіва- } \\
\text { лентний } \\
L_{\mathrm{E}}\end{array}$ & $\begin{array}{c}\text { Макси- } \\
\text { мальний } \\
L_{\max }\end{array}$ \\
\hline \multicolumn{4}{|l|}{ Територія, прилегла до: } \\
\hline \multirow{2}{*}{ будинків лікарень, санаторіїв; } & $8-22$ & 45 & 60 \\
\hline & $22-8$ & 35 & 50 \\
\hline \multirow{2}{*}{$\begin{array}{l}\text { житлових будинків, } \\
\text { поліклінік, амбулаторій, диспансерів, } \\
\text { будинків відпочинку, пансіонатів, } \\
\text { будинків інтернатів для людей } \\
\text { похилого віку та інвалідів, дитячих } \\
\text { дошкільних установ, шкіл та інших } \\
\text { навчальних закладів, бібліотек }\end{array}$} & $8-22$ & 55 & 70 \\
\hline & $22-8$ & 45 & 60 \\
\hline \multirow{2}{*}{ будинків готелів та гуртожитків } & $8-22$ & 60 & 75 \\
\hline & $22-8$ & 50 & 65 \\
\hline \multirow{2}{*}{ офісних будівель } & $8-22$ & 65 & 80 \\
\hline & $22-8$ & 55 & 70 \\
\hline \multicolumn{4}{|l|}{$\begin{array}{l}\text { Майданчики для } \\
\text { території: }\end{array}$} \\
\hline лікарень і санаторіїв; & - & 35 & 50 \\
\hline $\begin{array}{l}\text { житлових кварталів та груп житлових } \\
\text { будинків, будинків відпочинку, } \\
\text { пансіонатів, будинків інтернатів для } \\
\text { людей похилого віку та інвалідів }\end{array}$ & - & 45 & 60 \\
\hline $\begin{array}{l}\text { майданчики на території дитячих } \\
\text { дошкільних установ, шкіл та інших } \\
\text { навчальних закладів }\end{array}$ & - & 45 & 60 \\
\hline
\end{tabular}

Так як шумове забруднення $є$ проблемою державного рівня, законодавчими та нормативно-правовими документами [4-8] передбачені 
заходи для відвернення, зниження $\mathrm{i}$ досягнення безпечних рівнів виробничих та інших шумів, а саме:

- створення і впровадження малошумних машин і механізмів;

- удосконалення конструкцій транспортних та інших пересувних засобів і установок та умов їх експлуатації, а також утримання в належному стані залізничних і трамвайних колій, автомобільних шляхів, вуличного покриття;

- розміщення підприємств, транспортних магістралей, аеродромів та інших об'єктів 3 джерелами шуму під час планування і забудови населених пунктів відповідно до встановлених законодавством санітарно-гігієнічних вимог, будівельних норм та карт шуму;

- виробництво будівельних матеріалів, конструкцій, технічних засобів спорудження житла, об'єктів соціального призначення та будівництво споруд з необхідними акустичними властивостями;

- організаційні заходи для відвернення і зниження виробничих, комунальних, побутових i транспортних шумів, включаючи запровадження раціональних схем і режимів руху транспорту та інших пересувних засобів і установок у межах населених пунктів.

Окрім цих заходів є також архітектурно-планувальні, будівельноакустичні, організаційно-технічні методи, спрямовані на зниження шуму в джерелі його виникнення, одним із таких методів являється встановлення шумозахисних екранів.

Акустичний (шумозахисний) екран - перепона встановлена на шляху між джерелом шуму і місцем спостереження, що викликає виникнення так званні акустичної тіні. Акустичний екран [2] являє собою конструкцію 3 панелей акустичного захисту встановлених у певній системі несучої конструкції з бетонних або сталевих стійок.

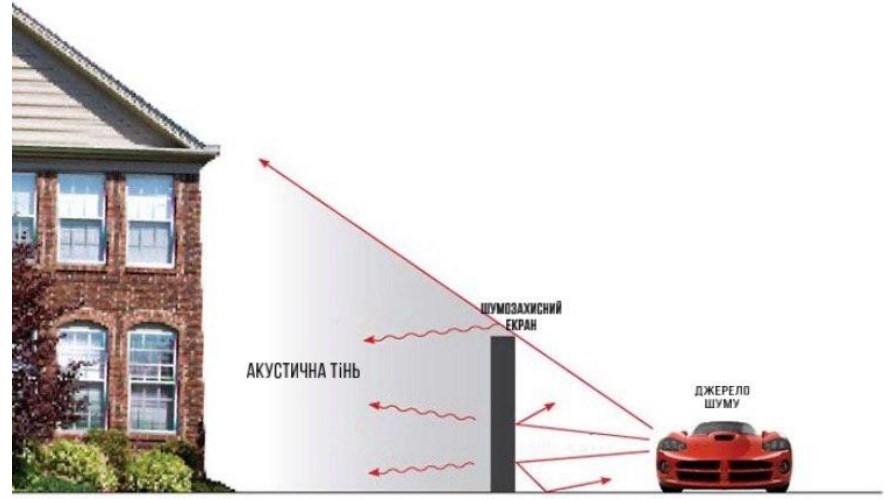

Рис. 1. Принцип дії акустичного екрану 
На рис. 1. зображено прямий шлях шуму від джерела до приймача, який переривається шумозахисним екраном. Залежно від шумозахисного матеріалу та обробки поверхні, частина вихідної шумової енергії відбивається або розсіюється назад до джерела. Проте повністю усунути шум неможливо.

За принципом дії розрізняють 3 основних типи екранів [9-11]: поглинаючі, відбиваючі, комбіновані. Їх встановлюють не лише біля автомобільних доріг, а й біля залізничних колій, аеропортів та інших локалізованих джерел шуму.

Шумопоглинаючий - монтується 3 важких матеріалів, таких як бетон, панелі з функцією шумопоглинання сприймають на себе звукову хвилю, яка, проходячи через спецматеріали, втрачає свою силу. Використовуються такі екрани на ділянках, де необхідний захист від шуму без нанесення шкоди протилежній від конструкції стороні. В основному звукопоглинальні панелі встановлюються на автотрасах 3 великим вантажопотоком.

Шумовідбиваючий - листи з плоскою рівною поверхнею (такі, як монолітний або стільниковий лист) мають властивість знижувати звук в основному завдяки його відображенню. Прозорі акустичні бар'єри можуть знизити рівень шуму більш, ніж на 30 Дб, товщина листа, що використовують для спорудження акустичного бар'єру, безпосередньо впливає на його ефективність. Завдяки високій здатності пропускати світло, шумовідбивні екрани мають можливість огляду та перешкоджають виникненню тунельного ефекту.

Конструкція комбінованих екранів містить у собі шумопоглинальні панелі в сполученні з шумовідбивними екранами.

3 огляду на закони поширення шумових хвиль, для правильного та ефективного шумозахисного екрану необхідно виконати акустичний проект, у якому будуть визначені геометричні розміри, конфігурація та розташування його елементів.

Ефективність шумових бар'єрів залежить від їх висоти. Екран повинен бути вищий, ніж джерело шуму. Зазвичай це 2-3 м, але буває i більше - до 6 метрів. Шумозахисні паркани нижче 2,5 м не можуть як слід виконувати свої функції.

Екрани виготовляють 3 різних матеріалів, залежно від цих матеріалів вони можуть бути прозорими та непрозорими. Прозорі шумозахисні екрани мають певні переваги над іншими, оскільки дозволяють бачити навколишній ландшафт, тим самим запобігаючи відчуття закритості або відгородження.

Захисні паркани будують із матеріалів 3 високим коефіцієнтом відображення енергії звукової хвилі. Для цього використовують: полікарбонат, скло, а рідше - бетон. Часто ці матеріали комбінують між собою. 
Полікарбонат володіє чудовими звукоізоляційними якостями і має естетичний зовнішній вигляд. До того ж, він може пропускати світло, створюючи більш комфортні умови, ніж при використанні глухого паркану. Використовують сотовий або монолітний полікарбонат.

Скляні шумозахисні екрани виготовляють із загартованого матеріалу. Виходить міцна і красива огорожа, але досить дорога в порівнянні 3 екраном, виготовленим 3 полікарбонату. Високий паркан зі скла не створює перешкод 3 видимістю, пропускає світло, стійкий до різних атмосферних явищ. Однак, такий паркан складно встановлювати - для цього потрібні спеціальні навички та інструменти.

Нижче наведено порівняльну характеристику шумопоглинання полікарбонату в порівнянні зі склом [12-14] (табл. 2).

Таблиця 2

Рівень поглинання шуму залежно від матеріалу акустичного екрану

\begin{tabular}{|c|c|c|c|}
\hline $\begin{array}{c}\text { Товщина } \\
\text { матеріалу }\end{array}$ & $\begin{array}{c}\text { Сотовий } \\
\text { полікарбонат, } \\
\text { Дб }\end{array}$ & $\begin{array}{c}\text { Монолітний } \\
\text { полікарбонат, } \\
\text { Дб }\end{array}$ & Скло, Дб \\
\hline 3 мм & - & 23 & - \\
\hline 4 мм & 6 & 25 & 29 \\
\hline 5 мм & - & 27 & 30 \\
\hline 6 мм & 8 & 29 & 31 \\
\hline 8 мм & 13 & 31 & 32 \\
\hline 10 мм & 20 & 33 & 33 \\
\hline 12 мм & - & 34 & 34 \\
\hline 15 мм & - & 35 & - \\
\hline 16 мм & 21 & - & - \\
\hline 20 мм & 22 & - & - \\
\hline 25 мм & 23 & - & - \\
\hline 32 мм & 25 & - & \\
\hline
\end{tabular}

Незважаючи на ранні дослідження, які розпочались в Америці у 1958 році, перша шумозахисна стіна 3'явилась у 1968 році. Вона була побудована в штаті Каліфорнія. Пізніше, із прийняттям закону про боротьбу із шумом 1972 року, так звані звукові стіни почали поширюватися по всій країні.

3 часом шумозахисні екрани удосконалювались, так, наприклад у Нідерландах розпочались тестування бар'єрів, що здатні не лише захищати від шуму, а й виробляти електрику за допомогою енергії сонця. Це велике досягнення, адже тепер екрани зможуть не тільки захищати від шуму та пилу, але й забезпечувати мешканців населених пунктів електрикою. 


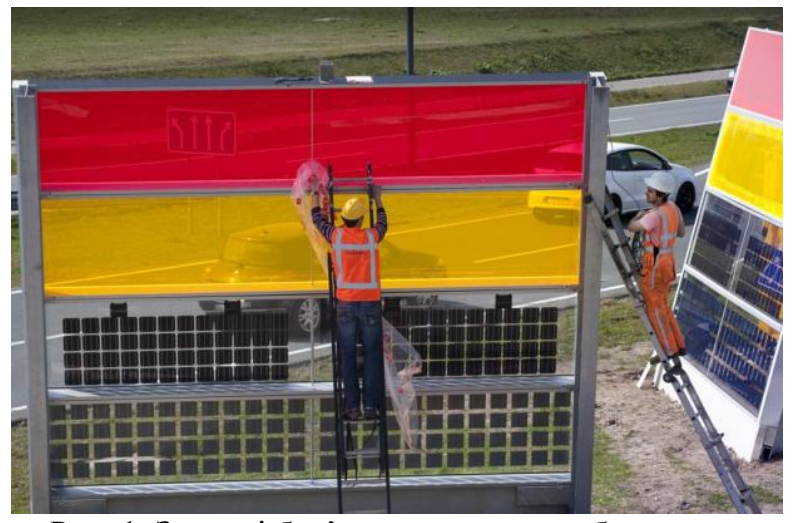

Рис. 1. Звукові бар'єри з сонячними батареями

Висновки. Розглянувши особливості та параметри шумозахисних екранів, можна виділити їхні основні позитивні та негативні характеристики. Основною перевагою використання шумозахисних екранів $\epsilon$, звичайно, значне зниження рівня шуму та захист від бруду та пилу, які надходять 3 дороги. Розглядаючи окремо екрани з полікарбонату, можна відзначити, що на цей матеріал не впливають несприятливі погодні умови, він стійкий до ультрафіолетового випромінювання, не піддається корозії. Прозорі матеріали забезпечують хорошу пропускну здатність світла, легка вага та гнучкість полегшує обробку, а також монтаж.

Недоліками є відносно висока вартість встановлення, паркан повинен бути суцільним, адже навіть невеликі тріщини в конструкції зменшують ефективність усього екрану, взимку є можливість утворення снігових заметів.

\section{References}

1. Kucheriavy V.P. Urban Ecology: Textbook / V.P. Kucheriavy. - Lviv: World, 2002. $-439 \mathrm{p}$.

2. Noise protection in urban planning / H.L. Osipov, V.E Korobkov, A.A Klymukhyn, etc. - M .: Stroyizdat, 1993. - 96 p.

3. L.Y Karahodyna City and noise. Nature / L.Y Karahodyna. - M: 1993.

4. DBN B.2.2-12: 2018 "Planning and Development of Territories"

5. DBN B.1.1-31: 2013 "Protection territories of buildings and structures from noise"

6. DSP 173. "State Sanitary Rules for Planning and Development of Settlements"

7. Law of Ukraine "On the Protection of Atmospheric Air"

8. Law of Ukraine "On ensuring the sanitary and epidemiological well-being of the population"

9. Novak S.M., Lohvvnets A.S. Protection from noise and vibration in construction. - K .: Stroitel, 1990. - 194 p. 
10. Petruk V.H., Kvaterniuk S.M., Turchyk P.M., Tyshchenko O.O. Constructionacoustic ways reducing the traffic noise of motorways [Electronic resource]. Access mode: http://eco.com.ua/content/budivelno-akustichni-zasobi-znizhennya-transportnogoshumu-avtomagistralei-0

11. On Highway Noise Barriers, The Science Is Mixed. Are There Alternatives? [Electronic resource]. Access mode: https://undark.org/2017/12/27/highway-noisebarrier-science/

12. Noise-protection screens. Polycarbonate as a material for noise protection. [Electronic resource]. Access mode: https://plastimet.prom.ua/a227431-shumosahisniekrani-polikarbonat.html

13. Noise-protection screens. [Electronic resource]. Access mode: https://ektokom.wixsite.com/index/blank-3

14. Noise-protecting (sound-reflecting, noise-absorbing) fences. [Electronic resource]. Access mode: http://gorodsad.in.ua/shumozakhysni-zvukootrazhaiushchyeshumopohlynaiuchi-parkany.html

\section{Список використаної літератури}

1. Кучерявий В. П. Урбоекологія: Підручник / В. П. Кучерявий. - Львів: Світ, 2002. - 439 с.

2. Защита от шума в градостроительстве / Г. Л. Осипов, В. Е. Коробков, А. А. Климухин и др. - М.: Стройиздат, 1993. - 96 с.

3. Карагодина Л. И. Город и шум. Природа / Л. И. Карагодина. - М: 1993.

4. ДБН Б.2.2-12:2018 "Планування і забудова територій”

5. ДБН В.1.1-31:2013 “Захист територій будинків і споруд від шуму” пунктів"

6. ДСП 173. “Державні санітарні правила Планування і забудови населених

7. Закон України "Про охорону атмосферного повітря"

8. Закон України "Про забезпечення санітарного та епідемічного благополуччя населення",

9. Новак С. М., Логвинец А. С. Защита от шума и вибрации в строительстве. - К.: Строитель, 1990. - 194 с.

10. Петрук В. Г., Кватернюк С. М., Турчик П. М., Тищенко О.О.. Будівельноакустичні засоби зниження транспортного шуму автомагістралей - [Електронний pecypc]. - режим доступу: http://eco.com.ua/content/budivelno-akustichni-zasobiznizhennya-transportnogo-shumu-avtomagistralei-0

11. On Highway Noise Barriers, the Science Is Mixed. Are There Alternatives? [Електронний ресурс]. - режим доступу: https://undark.org/2017/12/27/highwaynoise-barrier-science/

12. Шумозахисні екрани. Полікарбонат як матеріал для захисту від шуму. [Електронний ресурс]. - режим доступу: https://plastimet.prom.ua/a227431shumozahisni-ekrani-polikarbonat.html

13. Шумозахисні екрани. - [Електронний ресурс]. - режим доступу: https://ektokom.wixsite.com/index/blank-3

Шумозахисні (звукоотражающие, шумопоглинаючі) паркани. - [Електронний pecypc]. - режим доступу: http://gorodsad.in.ua/shumozakhysni-zvukootrazhaiushchyeshumopohlynaiuchi-parkany.html 